Wu, D., Yu, L., Zhu, S. \& Wang, Q. (2021).Teachers' profiles of ICT-related dispositions and relations to secondary school students' information literacy: a latent profile analysis. Journal of Educational Technology Development and Exchange, 14(2), 21-40.

\title{
Teachers' profiles of ICT-related dispositions and relations to secondary school students' information literacy: a latent profile analysis
}

\author{
Di Wu \\ Central China Normal University \\ wudi@mail.ccnu.edu.cn \\ Liqin Yu \\ Hubei University of Technology \\ 352302509@qq.com \\ Sha Zhu \\ Central China Normal University \\ zhusha@mail.ccnu.edu.cn \\ Qin Wang \\ Central China Normal University \\ 1329857649@qq.com
}

\begin{abstract}
Teachers play a significant role in integrating information and communication technology (ICT) in schools as well as in fostering information literacy among students. However, there is a lack of research that focuses on the differential influence of teachers' profiles concerning ICT-related dispositions on students' information literacy. To fill this gap, the present study examined whether teacher profiles differ in terms of their ICT-related dispositions. If so, the relationship between the identified teachers' profiles and their students' information literacy was investigated. Three distinct teacher profiles were identified based on their ICT-related dispositions: negative users, moderate users, and positive users. In addition, teachers' ICTrelated dispositions were found to significantly affect students' information literacy. Specifically, students from schools with a higher percentage of positive teachers demonstrated higher levels of information literacy than other students. This finding confirms the importance of teachers' ICT-related dispositions for improving students' information literacy. Based on these findings, this paper discusses several implications and strategies for enhancing teachers' ICT-related dispositions, as well as students'information literacy.
\end{abstract}

Keywords: teachers' profile, ICT-related dispositions, students' information literacy, latent profile analysis 


\section{Introduction}

Information literacy refers to the ability to use information technology to effectively access, create, manage, and critically evaluate information (Fraillon et al., 2015). Information literacy has been recognized as a form of meta literacy that helps people to acquire competencies and skills for achieving professional success and private goals across their lifespan (Senkbeil \& Ihme, 2017). Through policy statements, many countries have officially recognized the importance of developing information literacy for providing a foundation for students' productive future participation in economy and society (Zhu et al., 2019).

Teachers play a significant role in integrating information and communication technology (ICT) in schools and in fostering students' information literacy (Uluyol \& Şahin, 2016). Prior studies demonstrated that teachers' ICT-related dispositions such as teachers' ICT self-efficacy, frequent ICT usage in collaboration with others, utilization of ICT in teaching, and ICT attitude do affect students' information literacy (Aesaert et al., 2015; Yu, Wu, Zhu, Chen, \& Zhu, 2020; Zhu et al., 2019). However, most studies assume teacher homogeneity, and treat teachers as a holistic unit, while not considering their individual differences. Only one study attempted to categorized teachers into different groups, but this classification was only based on the dimension of teachers' general ICT attitudes, attitudes towards ICT in education, ease of use, and ICT self-efficacy (Tondeur, Scherer, Siddiq, \& Baran, 2017). However, the impact of different teacher groups on their students' information literacy was not assessed.
Thus, there is a lack of research that focuses on the differential influence of teachers' profiles, i.e., categories of teachers, concerning ICT-related dispositions on students' information literacy. Given the potential diversity among teacher's ICTrelated dispositions, it is of critical importance to conduct a deeper and more complex investigation of these differences in teachers' influences on students' information literacy. Without a comprehensive and nuanced understanding of teachers' influence on students' information literacy, it is difficult to effectively capitalize on any type of intervention that aims to promote students' information literacy.

Therefore, the present study (1) examined whether different teacher profiles exist in terms of teachers' ICT-related dispositions, and, if so, (2) investigated the relationship between the identified teachers' profiles and their students' information literacy. The results of this study provide new insights into the understanding of teachers' influences on students' information literacy. These insights may be beneficial for providing differentiated strategies and supporting mechanisms for effectively cultivating students' information literacy from the teachers' perspective.

\section{Theoretical Framework}

In this section, we will discuss students' information literacy, and several key components concerning with teachers' ICTrelated dispositions, including teachers' motivation to use ICT in teaching, teachers' educational ICT use, teachers' ICT competence, teachers' emphasis on developing students' digital citizenship, teachers' attitude towards ICT. 


\subsection{Students' Information Literacy}

Various institutions and researchers have put forward a variety of definitions of information literacy. For example, the UNESCO (2010) defined information literacy as the ability to identify, locate, evaluate, organize, and effectively create, use, and communicate information. The Educational Testing Service (ETS) defined information literacy as the ability to use digital technology and networks to access, manage, integrate, evaluate, and create information (Katz, 2007). The Association of College and Research Libraries (ACRL) defined information literacy as a set of comprehensive abilities encompassing the reflective discovery of information, the understanding of how information is produced, and the recreation of new knowledge (ACRL, 2016). More recently, with the rapid development of art intelligence, big data, and cloud computing, computational thinking has become an important element for future talents and has been identified as a new dimension of students' information literacy (Kim, Ahn, \& Kim, 2019; Kim, Kim, Na, \& Lee, 2021).

By consolidating the existing definitions of information literacy and based on our previous work (Zhu, Yang, MacLeod, Yu, \& Wu, 2019), this paper proposes four dimensions of information literacy: information awareness and attitude, information knowledge and skills, information thinking and behavior, and information social responsibility (Zhu et al., 2020).

\subsection{Teachers' Motivation to Use ICT in Teaching}

Motivation refers to personal characteristics that drive an individual toward performing actions and achievement (Kao,
Wu, \& Tsai, 2011; Pinder, 2014). It has been proposed that people expend effort because of two typical categories of motivation: extrinsic and intrinsic motivation (Teo, Lim, \& Lai, 1999). Extrinsic motivation is defined as the performance of an activity for achieving externally valued outcomes such as salaries, fringe benefits, and job security. Intrinsic motivation refers to the desire to perform activities that are perceived as interesting, and that are performed for their own inherent satisfaction (Chigona, Chigona, \& Davids, 2014).

It has been empirically demonstrated that the intrinsic and extrinsic motivations of teachers play a critical role when making decisions associated with the use of ICT in the classroom (Uluyol \& Şahin 2016). Ramayah, Jantan, \& Ismail (2003) indicated that variables of intrinsic motivation such as perceived ease of use and perceived enjoyment were positively related to frequency of daily Internet use. Monacis, Ceglie, Limone, Tanucci, \& Sinatra (2019) showed that teachers' perceived enjoyment predicted their ICT integration into educational practices. Chigona, Chigona, \& Davids (2014) reported that teachers' motivation to use technology for curriculum delivery could be impacted by their level of satisfaction derived from using ICTs, individual expectations, responsibility, and their sense of achievement experienced when using technologies. Prior studies also reported that certain external factors impacted teachers' motivation to use ICT in class. For example, Agyei and Voogt (2011) demonstrated that a lack of ICT training programs was a major barrier influencing teachers' motivation for using ICT in class. Although the impact of teachers' motivation on their ICT use in teaching has been extensively examined, few studies focused on the effect of teachers' motivation on students' information literacy. 


\subsection{Teachers' Educational ICT Use}

Educational ICT use has been measured by reporting the time teachers or students spend using technology or the amount of technology used (Mathews \& Guarino, 2000; O'Dwyer, Russell, \& Bebell, 2004). Other studies assessed educational ICT use from specific ICT activities. For example, Ainley, Banks, and Fleming (2002) identified three categories of teachers' educational computer use such as "computers as information resource tools", "computers as authoring tools", and "computers as knowledge construction tools". Tondeur, van Braak, and Valcke (2007) categorized teachers' computer use in primary education into three profiles: "basic computer skills", "the use of computers as an information tool", and "the use of computers as a learning tool". The findings of Masoumi (2015) showed that teachers' use of ICT could be categorized into four distinctive modes: using ICT to enrich and transform existing curriculum and practices, using ICT to enhance children's cultural literacy, using ICT to entertain young children, and using ICT for communicating and documenting preschool practices. Sang, Valcke, van Braak, Tondeur, \& Zhu (2011) demonstrated that two distinctive types of ICT use could be distinguished in the Chinese context: (a) teacher supportive use of ICT and (b) classroom use of ICT for supporting and enhancing the teaching and learning processes.

Prior studies showed that teachers' educational ICT use played a critical role in developing students' information literacy. For example, Aesaert et al. (2015) found that the use of ICT in teaching activities positively impacts students' information literacy level in digital information processing and communication. According to $\mathrm{Yu}$ et al.
(2020), in rural schools, teachers' ICT use for promoting students' learning was negatively associated with students' information literacy. In addition, teachers' ICT-related collaboration has been identified as a key factor influencing students' information literacy. For example, Lai et al. (2014) claimed that a collaborative teaching approach using ICT positively impacts students' information literacy level. Similarly, Zhu et al. (2019) indicated that teachers with higher ICT self-efficacy and frequent ICT usage when collaborating with others more positively influenced students' information literacy.

\subsection{Teachers' ICT Competence}

ICT competence can be defined as the functional use of digital knowledge, skills, and attitudes, and presents a more comprehensive view of the use of technology (Danner \& Pessu, 2013; Tondeur, Aesaert, Pynoo, et al., 2017). Researchers have emphasized different aspects of teachers' ICT competence. For example, Almerich, Orellana, SuárezRodríguez, \& Díaz-García (2016) reported that teachers' ICT competence is composed of two subsets: technical competence and pedagogical competence. Qizhong and Qing (2012) reported that teachers' ICT competence should contain personal use of ICT, use of ICT as a tool for teaching, use of ICT as a mind tool, and use of ICT to promote their professional development.

Existing research proved that teachers' ICT competency may affect teachers' ICT usage in their teaching. For example, Almerich, Orellana, Suárez-Rodríguez, et al. (2016) claimed that teachers' ICT competence has been identified as a key variable for integrating technology and resources into the teaching-learning process. Buabeng- 
Andoh (2012) demonstrated that teachers' ICT competence and confidence were predictors of ICT usage in their teaching. Similarly, Sorgo, Verckovnik, and Kocijancic (2010) found a high correlation between teacher ICT competency and the frequency of their ICT use and perceived importance of ICT. Yusuf and Balogun (2011) showed that teachers who did not have basic computer operational skills were also not able to integrate ICT into their school curriculum. However, to the best of our knowledge, the relationship between these different types of teachers' educational ICT use and students' information literacy has not been investigated to date.

\subsection{Emphasis on Developing Students' Digital Citizenship}

Digital citizenship is broadly viewed as the ability to use technology and the Internet appropriately, safety, and responsibly (Ribble, 2004). As the Internet changes the way young people learn, live, and work, the ethical issues regarding potential risks and maintaining safety, privacy, and health when using ICT has been acknowledged as an important dimension of digital citizenship (Choi, 2016). According to UNESCO (2020), digital citizenship is defined as "the competences that allow people to access, understand, analyze, produce and use the digital environment in a critical, ethical and creative way".

The construct of teachers' emphasis on developing students' digital citizenship (TEDDCS) was developed from the subscales of teachers' ICT integration skills (Hsu, 2010). TEDDCS aims to gauge the extent with which teachers encourage their students to use information ethically and provide guidance regarding protecting themselves from the dangers of cyberbullying, sexting, and harmful contacts (Gleason, \& Von Gillern, 2018; Van Laar, Van Deursen, Van Dijk, \& De Haan, 2017).

\subsection{Teachers' Attitude towards ICT}

Attitude involves individuals' preferences and aversions, towards specific aspects of the external world (Baron \& Byrne, 1987, 137). Accordingly, attitude toward ICT could be regarded as beliefs, values, and judgements persons hold about information technology. Prior studies showed that the attitude of teachers towards the use of ICT affected their implementation of ICT use at school. For example, Sang et al. (2011) suggested that attitudes towards computers affect teachers' acceptance of the usefulness of technology, and affect whether teachers will integrate ICT into their classrooms. According to Copriady (2014), teachers' positive attitude can facilitate their use of more instructional technology tools to make learning more interesting and attractive for their students. Moreover, the findings of Jegede, Dibu-Ojerinde, \& Ilori (2007) indicated that teachers' ICT attitude plays an important role in developing their ICT competence. In other words, if teachers perceive computers to be useful in their pedagogical enterprise, their interests become aroused which, in turn, helps the development of their computer skills.

Regarding the impact of teachers' ICT attitudes on students' information literacy, the findings of prior studies were inconsistent. For example, Meelissen and Drent's (2008) reported that teachers' ICT attitude positively affects students' information literacy via students' ICT attitude. In contrast, Zhu, Yang, MacLeod, Yu, \& Wu (2019) demonstrated that teachers' with a more positive attitude towards the use of ICT seemed to exert a more 
negative impact on students' information literacy. Thus, it is necessary to re-examine the impact of teachers' ICT attitude on students' information literacy.

\subsection{The Present Study}

Prior studies have examined the impact of teachers' ICT attitude, ICT self-efficacy, ICT use for teaching, and ICT collaboration with others on students' information literacy. However, other ICT-related dispositions such as teachers' motivation to use ICT in teaching, teachers' ICT competences, and teachers' emphasis for developing students' digital citizenship have received less attention. Moreover, the uniqueness of each teacher in terms of ICT-related dispositions has not been investigated and the impact of each teachers' distinctive profile on their students' information literacy has not been explored. To fill this research gap, the present study poses the following research questions:

RQ 1: Which profiles can be identified among secondary school teachers based on their ICT-related dispositions (i.e., teachers' ICT attitude, teachers' educational ICT usage, teachers' ICT competence, and teachers' emphasis for developing students' digital citizenship)? If such groups exist, what characterizes them?

RQ 2: If RQ 1 holds, are the identified teachers' profile memberships related to their students' performance in information literacy?

\section{Methodology}

In order to investigate the two research questions, quantitative method was employed in this study. Specifically, two survey questionnaires regarding with students' information literacy and teachers' ICT-related dispositions, were administered to students and teachers respectively. Then, latent profile analysis (LPA), which is a statistics method for distinguishing homogenous subgroups from heterogeneous samples (Rosenberg et al. 2019), was utilized in this study to identify teachers' profiles concerning with ICT-related dispositions. Finally, regression analysis was conducted to explore the relationship between teachers' profile memberships and their students' information literacy.

\subsection{Participants}

A total of 109,270 students and 9591 teachers from 238 schools across Ningxia autonomous region, located in northwest China, were invited to take part in this study. In recent years, the government of Ningxia autonomous region has announced the 'Intelligence + Education Demonstration Region Construction Master Plan (20182022)'. This plan emphasizes the importance of improving students' information literacy and its incorporation into comprehensive quality assessment systems (The Office of The People's Government of Ningxia autonomous region, 2018). Considering the possibility that stress related to entrance examinations for senior school may lead to certain inaccuracies in the results, it was decided that ninthgrade students should be excluded from the sample. Therefore, the sample included only seventh-grade $(\mathrm{n}=54,992)$ and eighth-grade $(n=54,278)$ students. The average age of participants ranged between 12 and 14 years.

Aided by provincial education administrative departments and local education administrative departments, students were placed into the computer lab of each sample school to complete the information 
literacy test. At the same time, 9591 teachers of selected schools were required to complete the teacher questionnaire. Students and teachers were matched through the schools' name. All participants were informed that their information would only be used for educational research purposes and that their survey results would not affect their grades.

\subsection{Instrumentation}

Students' information literacy was measured through an online Student Information Literacy Test. This test was specifically designed by our research team and included four dimensions of information literacy: information awareness and attitude
(12 items), information knowledge and skills (16 items), information thinking and behavior (6 items), and information society responsibility (6 items). All items were multiple choice questions with four answers, and students were asked to choose the best answer (Zhu et al., 2020).

Teacher data was collected via five scales. These scales include teachers' motivation to use ICT in teaching, teachers' educational ICT use, teachers' ICT competence, teachers' ICT positive attitude, and teachers' emphasis for developing students' digital citizenship. Table 2 lists these five scales, the corresponding sample questions, as well as their sources.

Table 1. Teachers' questionnaire and sample questions.

\begin{tabular}{|c|c|c|c|c|}
\hline \multicolumn{2}{|c|}{ Instruments measure } & Sample item & $\begin{array}{l}\text { Number } \\
\text { of items }\end{array}$ & Source \\
\hline \multirow{2}{*}{$\begin{array}{l}\text { Teachers' } \\
\text { motivation } \\
\text { to use ICT }\end{array}$} & $\begin{array}{l}\text { External } \\
\text { motivations }\end{array}$ & $\begin{array}{l}\text { School leaders encouraged me to integrate } \\
\text { information technology with teaching. } \\
\text { A. Strongly disagree B. Disagree C. } \\
\text { Neutral D. Agree E. Strongly agree }\end{array}$ & 5 items & $\begin{array}{l}\text { Papanastasiou } \\
\text { \& Angeli } \\
(2008)\end{array}$ \\
\hline & $\begin{array}{l}\text { Internal } \\
\text { motivations }\end{array}$ & $\begin{array}{l}\text { I use information technology in my } \\
\text { teaching because I like to experiment with } \\
\text { new technologies. } \\
\text { A. Strongly disagree B. Disagree C. } \\
\text { Neutral D. Agree E. Strongly agree }\end{array}$ & 5 items & $\begin{array}{l}\text { De Pablos- } \\
\text { Pons et al., } \\
(2012)\end{array}$ \\
\hline $\begin{array}{l}\text { Teachers' } \\
\text { educational } \\
\text { ICT use }\end{array}$ & $\begin{array}{l}\text { ICT use for } \\
\text { teaching } \\
\text { practice }\end{array}$ & $\begin{array}{l}\text { In the classroom, I use information } \\
\text { technology to provide students with } \\
\text { learning materials. } \\
\text { A. Never B. Rarely C. Occasionally D. } \\
\text { Very often E. Always }\end{array}$ & 14 items & $\begin{array}{l}\text { Carstens } \\
\text { \& Pelgrum } \\
(2009)\end{array}$ \\
\hline
\end{tabular}




\begin{tabular}{|c|c|c|c|c|}
\hline \multirow{2}{*}{$\begin{array}{l}\text { Teachers' } \\
\text { educational } \\
\text { ICT use }\end{array}$} & $\begin{array}{l}\text { ICT use for } \\
\text { collaboration }\end{array}$ & $\begin{array}{l}\text { I communicate with other teachers } \\
\text { about the idea of integrating information } \\
\text { technology and teaching. } \\
\text { A. Never B. Rarely C. Occasionally D. } \\
\text { Very often E. Always }\end{array}$ & 5 items & $\begin{array}{l}\text { Carstens } \\
\text { \& Pelgrum } \\
(2009)\end{array}$ \\
\hline & $\begin{array}{l}\text { ICT use for } \\
\text { professional } \\
\text { development }\end{array}$ & $\begin{array}{l}\text { I actively take part in school-based } \\
\text { training related to information technology. } \\
\text { A. Never B. Rarely C. Occasionally D. } \\
\text { Very often E. Always }\end{array}$ & 4 items & $\begin{array}{l}\text { The Ministry } \\
\text { of Education } \\
(2014)\end{array}$ \\
\hline \multicolumn{2}{|c|}{ Teachers' ICT competence } & $\begin{array}{l}\text { I can prepare courses that require } \\
\text { students to participate using information } \\
\text { technology. } \\
\text { A. Strongly disagree B. Disagree C. } \\
\text { Neutral D. Agree E. Strongly agree }\end{array}$ & 5 items & $\begin{array}{l}\text { Carstens } \\
\text { \& Pelgrum } \\
(2009)\end{array}$ \\
\hline \multicolumn{2}{|c|}{$\begin{array}{l}\text { Teachers' ICT positive } \\
\text { attitude }\end{array}$} & $\begin{array}{l}\text { I believe that the application of } \\
\text { information technology in teaching and } \\
\text { learning can effectively help students } \\
\text { consolidate and process information. } \\
\text { A. Strongly disagree B. Disagree C. } \\
\text { Neutral D. Agree E. Strongly agree }\end{array}$ & 7 items & $\begin{array}{l}\text { Fraillon et al. } \\
(2015)\end{array}$ \\
\hline \multicolumn{2}{|c|}{$\begin{array}{l}\text { Teachers' emphasis on } \\
\text { developing students' } \\
\text { digital citizenship }\end{array}$} & $\begin{array}{l}\text { I require students to abide by the relevant } \\
\text { laws and regulations of intellectual } \\
\text { property. } \\
\text { A. Never B. Rarely C. Occasionally D. } \\
\text { Very often E. Always }\end{array}$ & 8 items & Hsu (2010) \\
\hline
\end{tabular}

To validate the psychometric quality of teachers' questionnaires, average variance extracted (AVE), composite reliability (CR), and Cronbach's alpha values for all factors were assessed. As shown in Table 2, the AVE values exceeded $0.50(0.56-0.64)$, the CR values exceeded 0.80 (0.83-0.95), and the Cronbach's alpha values exceeded 0.80 (0.82-0.95), indicating that this construct was validated as having satisfactory reliability (Helmstadter, 1964). Furthermore, to evaluate discriminant validity, the square roots of AVE were compared to correlations among latent variables, in which all latent correlations were less than the corresponding AVE square roots (Fornell \& Larcker, 1981). In conclusion, all items were reliable indicators. 
Table 2. Reliability and validity analysis.

\begin{tabular}{|c|c|c|c|c|c|c|c|c|c|c|c|}
\hline & AVE & $\mathrm{CR}$ & Cronbach's a & ES & IM & ТP & $\mathrm{CO}$ & $\mathrm{PD}$ & IA & $\mathrm{DC}$ & $\mathrm{PA}$ \\
\hline ES & 0.65 & 0.90 & 0.90 & 1 & & & & & & & \\
\hline IM & 0.56 & 0.83 & 0.82 & 0.474 & 1 & & & & & & \\
\hline $\mathrm{TP}$ & 0.66 & 0.91 & 0.90 & 0.311 & 0.345 & 1 & & & & & \\
\hline $\mathrm{CO}$ & 0.67 & 0.91 & 0.91 & 0.385 & 0.392 & 0.734 & 1 & & & & \\
\hline PD & 0.58 & 0.85 & 0.85 & 0.452 & 0.478 & 0.535 & 0.661 & 1 & & & \\
\hline IA & 0.61 & 0.89 & 0.90 & 0.478 & 0.497 & 0.566 & 0.655 & 0.811 & 1 & & \\
\hline $\mathrm{DC}$ & 0.74 & 0.93 & 0.93 & 0.356 & 0.379 & 0.564 & 0.623 & 0.589 & 0.662 & 1 & \\
\hline PA & 0.74 & 0.95 & 0.95 & 0.445 & 0.509 & 0.477 & 0.559 & 0.652 & 0.722 & 0.638 & 1 \\
\hline
\end{tabular}

Note: $\mathrm{ES}=$ External Support, IM = Internal Motivation, ICT_TP $=$ ICT use for teaching practice, ICT_CO = ICT use for collaboration, ICT_PD = ICT use for professional development, ICT_IA $=$ ICT competence, $\mathrm{DC}=$ teachers' emphasis for developing students' digital citizenship, $\mathrm{PA}=$ teachers' ICT positive attitude.

\subsection{Data collection}

This study was carried out in December 2019, with the assistance of the Education Department of Ningxia Hui Autonomous Region. The selection of participants was conducted using a two-stage cluster sampling method. In the first stage, several primary schools and secondary schools were selected randomly within each of the 22 districts and counties in Ningxia Hui Autonomous Region. In the second stage, teachers of different subjects in the sample schools were randomly selected as participants. A total of 109,270 students and 9591 teachers from 238 schools across Ningxia autonomous region participated in this study. All participants were informed of the research purposes and were required to sign a consent form to participate in the study.

\subsection{Data Analysis}

Data were screened and then imported into SPSS 25.0 for statistical analysis. Exploratory Factor Analysis (EFA) and confirmatory factor analysis (CFA) were employed to analyze the reliability and validity of the scales. Mplus 7.0 software was used for conducting LPA, which was preferred over standard approaches to cluster analysis, as it can significantly outperform standard approaches, such as the K-means technique (Magidson \& Vermunt 2002)

To find the best-fitting model, the following information criteria indices are recommended to determine the optional number of teachers' profiles: the Akaike information criterion (AIC), the Bayesian information criterion (BIC), the parametric bootstrapped likelihood ratio test (BLRT), and the entropy value. The entropy value ranges from 0 to 1 ; higher values indicate 
better distinctions between the groups and, therefore, better classification into relevant groups (Pastor et al. 2007; Wang et al. 2017). Smaller values of both AIC and BIC indicate better fitting models (Nylund, Asparouhov, $\&$ Muthén, 2007). Furthermore, the group size (profiles consisting of less than $5 \%$ of the sample were considered false) and the interpretability of the profiles were also considered to ensure that the profiles make theoretical sense and are generalizable (Hipp \& Bauer 2006; Marsh et al. 2009; Pastor et al. 2007). After identifying the latent teacher ICT-related dispositions profiles, differences in main effects of these measures were analyzed using univariate analysis of variance (ANOVA).

To examine the relationship between teachers' ICT related-dispositions profiles and students' information literacy, the number of three profiles of teachers in each school was counted. Then, regression analysis was conducted by SPSS25.0 to explore the number of three profiles of teachers and students' information literacy.

\section{Results}

Table 3. Fit indices and group sizes of the models.

\begin{tabular}{lllllll}
\hline Profiles & AIC & BIC & a-BIC & Entropy BLRT & Group Size \\
\hline 1 & 159952.7 & 160067.398 & 160016.552 & & & \\
2 & 134269.722 & 134448.937 & 134369.491 & 0.897 & $<0.001$ & 9591 \\
3 & 122574.691 & 122818.423 & 122710.376 & 0.926 & $<0.001$ & $6243 \backslash 3348$ \\
4 & 118981.73 & 119289.979 & 119153.332 & 0.866 & $<0.001$ & $1123 \backslash 5686 \backslash 2782$ \\
5 & 116656.487 & 117029.253 & 116864.005 & 0.851 & $<0.001$ & $2281 \backslash 4293 \backslash 548 \backslash 2469$ \\
6 & 114378.783 & 114816.066 & 114622.218 & 0.855 & $<0.001$ & $513 \backslash 4110 \backslash 1607 \backslash 1944 \backslash 1417$ \\
\hline
\end{tabular}

Note: $\mathrm{AIC}=$ Akaike information criterion; $\mathrm{BIC}=$ Bayesian information criterion; $\mathrm{a}-\mathrm{BIC}=$ adjusted Bayesian information criterion; BLRT $=$ parametric bootstrapped likelihood ratio test.

\subsection{The number of teachers' profiles}

To answer RQ 1, Mplus 7.0 was employed and latent profile analyses was performed with teachers' ICT-related dispositions (teachers' ICT motivation, teachers' ICT use, teachers' ICT competence, teachers' emphasis for developing students' digital citizenship, and teachers' ICT attitude). As shown in Table 3, an increasing number of profiles are associated with a decrease in information criteria (i.e., AIC, BIC, and adjusted BIC (a-BIC)). Entropy refers to the extent of precision of classification, where an entropy value close to 1 indicates a more accurate classification of the model (Morin et al., 2011). In addition, comparisons of the twoand three-profile models showed a significant drop in AIC and BIC indices (134269.722 $\rightarrow 122574.691,134448.937 \rightarrow 122818.423$, and $134369.491 \rightarrow 122710.376)$, indicating that the three-profile model was superior to the two-profile model. Thus, the three-profile model was accepted as the best-fit model. Additional support for the three-profile model is shown in Table 4. The average classification probabilities for Profile 1, Profile 2, and Profile 3 are all very high (Profile 1: 94.30\%; Profile 2: 96.90\%; Profile 3: 96.70\%). 
Table 4. Average latent class probabilities for the most likely latent class membership (row) by latent class (column)

\begin{tabular}{ccccc}
\hline & & 1 & 2 & 3 \\
\hline 1 & Profile 1 & $\mathbf{0 . 9 4 3}$ & 0.057 & 0.000 \\
2 & Profile 2 & 0.015 & $\mathbf{0 . 9 6 9}$ & 0.016 \\
3 & Profile 3 & 0.000 & 0.033 & $\mathbf{0 . 9 6 7}$ \\
\hline
\end{tabular}

Note: Values in bold reflect the average probability that participants were correctly categorized in the given latent profile.

\subsection{Description of teachers' profiles}

Based on latent profile analysis, the respondents were distributed among three profiles as follows: 1123 were classified as members of Profile 1, 5686 were classified as members of Profile 2, and 2782 were classified as members of Profile 3 . The differences between the mean scores of the three profiles were statistically significant for all scale scores. Table 5 shows the mean and standard deviations across all three identified profiles. Figure 1 provides a graphical representation of these data. The latent Profile 1 was named "negative users" and represented individuals with low levels of all scales of teachers' ICTrelated dispositions compared with other profiles. Latent Profile 2, labelled "moderate users", is the largest profile, comprising $59.28 \%$ of the entire sample. Teachers within this profile showed medium levels for the eight scales of ICT related dispositions. Latent Profile 3, identified as "positive users", involved $29.01 \%$ of the sample $(\mathrm{n}=2782)$. The "positive users" hold the highest of eight scales of ICT related dispositions compared with the other two profiles.

Table 5. Mean and standard deviation comparisons across the three identified profiles.

\begin{tabular}{|c|c|c|c|c|c|c|c|}
\hline \multirow{2}{*}{$\begin{array}{l}\text { Teachers' } \\
\text { ICT related } \\
\text { dispositions }\end{array}$} & \multicolumn{2}{|c|}{$\begin{array}{l}\text { Profile } 1(\mathrm{n}=1123) \\
\text { Negative Users }\end{array}$} & \multicolumn{2}{|c|}{$\begin{array}{l}\text { Profile } 2(\mathrm{n}=5686) \\
\text { Moderate Users }\end{array}$} & \multicolumn{2}{|c|}{$\begin{array}{l}\text { Profile } 3(\mathrm{n}=2782) \\
\text { Positive Users }\end{array}$} & \multirow[t]{2}{*}{$\mathrm{F}$} \\
\hline & M & SD & M & SD & M & SD & \\
\hline ES & 3.86 & 0.69 & 4.34 & 0.53 & 4.82 & 0.45 & $1498.57 * * *$ \\
\hline IM & 3.51 & 0.63 & 4.00 & 0.53 & 4.61 & 0.55 & $1937.86 * * *$ \\
\hline $\mathrm{TP}$ & 2.21 & 0.67 & 2.96 & 0.68 & 3.91 & 0.80 & $2723.73 * * *$ \\
\hline $\mathrm{CO}$ & 2.60 & 0.58 & 3.41 & 0.54 & 4.33 & 0.58 & $4539.82 * * *$ \\
\hline PD & 3.13 & 0.57 & 3.98 & 0.32 & 4.75 & 0.33 & $9064.20 * * *$ \\
\hline IA & 3.20 & 0.51 & 4.02 & 0.26 & 4.83 & 0.25 & $13649.36 * * *$ \\
\hline $\mathrm{DC}$ & 2.85 & 0.76 & 3.82 & 0.62 & 4.75 & 0.41 & $4635.36^{* * *}$ \\
\hline PA & 3.35 & 0.64 & 4.06 & 0.38 & 4.84 & 0.31 & $6393.55 * * *$ \\
\hline
\end{tabular}

Note: $\mathrm{ES}=$ External support, $\mathrm{IM}=$ Internal motivation, $\mathrm{TP}=\mathrm{ICT}$ use for teaching practice, $\mathrm{CO}$ $=$ ICT use for collaboration, PD = ICT use for professional development, IA = ICT competence, $\mathrm{DC}=$ teachers' em-phasis on developing students' digital citizenship, PA = teachers' ICT positive attitude. 


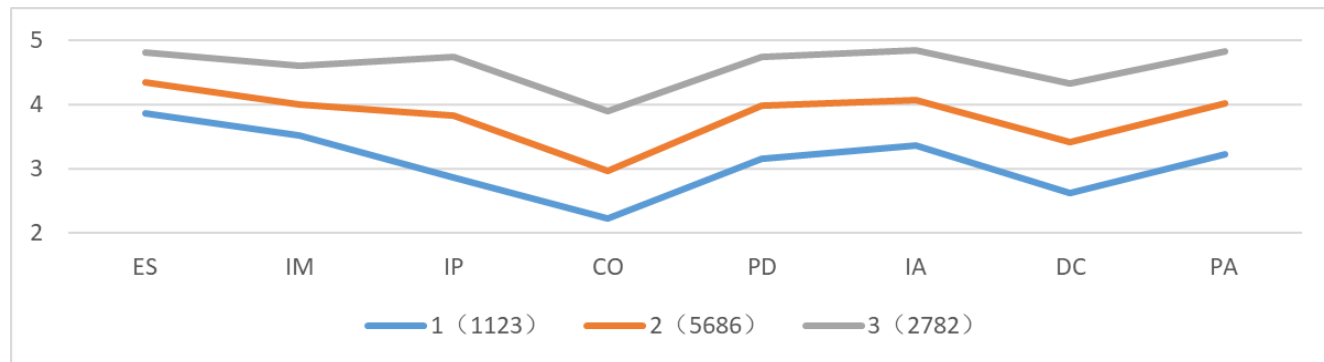

Figure 1. Graphical representation of the three profiles' means scores on teachers' ICT related dispositions.

Note: $\mathrm{ES}=$ External support, $\mathrm{IM}=$ Internal motivation, TP = ICT use for teaching practice, $\mathrm{CO}=$ ICT use for collaboration, $\mathrm{PD}=\mathrm{ICT}$ use for professional development, IA = ICT competence, DC = teachers' em-phasis on developing students' digital citizenship, $\mathrm{PA}=$ teachers' ICT positive attitude.

\subsection{Teacher profiles and students, information literacy}

Based on the classification of teacher categories, the percentages of teachers in different categories were calculated separately for each school. Then, regression analysis was employed to investigate the relationship between teachers' profiles and students' information literacy. As shown in Table 6, students' information literacy and other sub- dimensions were used as dependent variables, whereas the predictors were the number of teacher Profile 1, teacher Profile 2, and teacher Profile 3. Accordingly, the numbers of teacher Profile 2 and teacher Profile 1 were significant factors, which predicted students' information literacy and sub-dimensions negatively, while the number of teacher Profile 1 was identified as a positive significant factor of students' information literacy and sub-dimensions.

Table 6. Results of regression analysis between the number of three profiles of teachers and students' information literacy.

\begin{tabular}{lcccccc}
\hline \multicolumn{1}{c}{ Dependent variable } & Predictors & $B$ & $\mathrm{SE}$ & $\beta$ & $\mathrm{t}$ & $\mathrm{R}^{2}$ \\
\hline \multirow{2}{*}{$\begin{array}{l}\text { Students' information } \\
\text { literacy }\end{array}$} & Profile 1 & -0.23 & 0.02 & -0.08 & $-11.15 * * *$ & \\
& Profile 2 & -0.15 & 0.01 & -0.19 & $-22.33 * * *$ & 0.07 \\
& Profile 3 & 0.47 & 0.01 & 0.28 & $57.14 * * *$ & \\
\hline \multirow{2}{*}{$\begin{array}{l}\text { Information awareness } \\
\text { and attitude }\end{array}$} & Profile 1 & -0.09 & 0.01 & -0.10 & $-13.19 * * *$ & \\
& Profile 2 & -0.03 & 0.00 & -0.13 & $-15.62 * * *$ & 0.06 \\
& Profile 3 & 0.13 & 0.00 & 0.25 & $50.39 * * *$ & \\
\hline
\end{tabular}




\begin{tabular}{lcccccc}
\hline \multirow{2}{*}{$\begin{array}{l}\text { Information } \\
\text { knowledge and skills }\end{array}$} & Profile 1 & -0.03 & 0.004 & -0.043 & $-5.890^{* * *}$ & \\
& Profile 2 & -0.03 & 0.001 & -0.204 & $-24.158^{* * *}$ & 0.059 \\
& Profile 3 & 0.09 & 0.002 & 0.255 & $52.132 * * *$ & \\
\hline \multirow{2}{*}{$\begin{array}{l}\text { Information thinking } \\
\text { and behavior }\end{array}$} & Profile 1 & -0.070 & 0.005 & -0.109 & $-15.152 * * *$ & \\
& Profile 2 & -0.041 & 0.001 & -0.232 & $-28.333^{* * *}$ & 0.110 \\
& Profile 3 & 0.128 & 0.002 & 0.330 & $69.306 * * *$ & \\
\hline \multirow{2}{*}{$\begin{array}{l}\text { Information society } \\
\text { responsibility }\end{array}$} & Profile 1 & -0.064 & 0.009 & -0.056 & $-7.459 * * *$ & \\
& Profile 2 & -0.032 & 0.003 & -0.101 & $-11.820 * * *$ & 0.027 \\
\hline
\end{tabular}

\section{Discussion and Conclusion}

The purpose of this study was to explore the profiles of teachers' ICT-related dispositions and assess the relationship between the identified teachers' profiles and students' information literacy. Three distinct teacher profiles were identified based on their ICT-related dispositions: negative users, moderate users, and positive users. Most teachers (59.28\%) were grouped into the category of moderate users, $11.71 \%$ of the entire sample were classified as negative users, and only $29.01 \%$ were identified as positive users. Positive users used ICT frequently for teaching practices, professional development, and collaboration with other colleagues. These had the highest level of ICT motivation, ICT positive attitude, and ICT competence. Teachers in this group also attached great importance to developing students' digital citizenship and advocating safe, legal, and responsible use of information and technology in their daily life. Negative users demonstrated a low level of ICT competence, perceived negative attitudes toward ICT, received little external support, showed a low level of internal motivation of using ICT in their teaching practices.
They rarely used ICT in their teaching practices, professional development, and ICT collaboration. In addition, these groups of teachers also neglected the development of students' digital citizenship and did not encourage students to use ICT responsibly and appropriately. Compared with these two profiles, teachers of the moderate user group demonstrated a neutral attitude towards ICT, possessed a medium level of ICT competence, and perceived a basic level of external and internal ICT motivation. They use ICT occasionally for teaching practices, professional development, and collaborating with other teachers. Additionally, teachers within group of moderate users occasionally paid attention to the cultivation of students' digital citizenship.

The distinction of teachers' profiles provides deep insight into the patterns of their ICT-related dispositions. This could help researchers, practitioners, and policy-makers to better understand teachers' diversities, and also provides valuable information about teachers' potential needs for support. For example, the results showed that teachers who were grouped into negative users were not more competent especially in education ICT 
use such as using ICT for teaching practice, using ICT for collaboration, and using ICT for professional development. Thus, there is a great demand for teachers training programs and curricula that help to enhance teachers' ability for utilizing ICT for educational use.

Regarding RQ 2, the findings of this study extend the current understanding of how teachers' ICT-related disposition is linked to students' information literacy. In general, teachers' ICT-related disposition significantly affected students' information literacy. In other words, the number of teachers in a school who were identified as "positive users" has a positive impact on the information literacy of the students of the teachers in that school. In particular, students from schools with a higher percentage of teachers with positive disposition demonstrated higher levels of information literacy than other students. This finding confirms the importance of teachers' ICT-related dispositions for improving students' information literacy. Thus, to improve students' information literacy, the following strategies are proposed in terms of promoting teachers' ICT related dispositions.

Firstly, improving teachers' motivation and attitude in ICT teaching practices is of importance. It is important to activate teachers' intrinsic motivation sources and their attitude towards ICT from pedagogical, technical, and organizational aspects. Most importantly, educational departments and school administrators must believe in the value of the use of technology in education and organize regular public lectures to motivate teachers to integrate ICT into their teaching practice (Uluyoland \& Şahin, 2016). In addition, schools may hold competitions on the integration of ICT in education and encourage teachers to take part in these competitions (Gil-Flores, Rodríguez-Santero, \& TorresGordillo, 2017). Such experiences can lead to more comfort, confidence, acceptance, and eventually development of a positive attitude towards the integration of ICT into curricula and teaching (Copriady, 2014).

Secondly, the training of teachers' educational ICT use and ICT competence should be strengthened. It would be worthwhile for both the government and education administrators to organize diverse and regular training such as online teacher learning communities, blended learning, and peer learning for teachers. During the training process, teachers' feedback on the training should be collected continuously to enhance the pertinence of the training. In addition, teachers should connect with each other through teacher communities for supporting and guiding their ICT integration in the classroom (Aslan \& Zhu, 2016).

Thirdly, schools and teachers should attach great importance to the development of students' digital citizenship, as this is essential. First, teachers and schools should strongly emphasize society values and ideas promoting digital citizenship at the formal curriculum level. Second, teachers should integrate digital citizenship constructs into their regular teaching practices. For example, teachers are expected to teach students not only the skills to handle information, but also the ethical and civic issues connected with using the Internet and social media. In addition, teachers should provide guidance to students on how to protect themselves from the dangers of cyberbullying, sexting, and harmful exposure in their daily 
use of the Internet (Van Laar, Van Deursen, Van Dijk, \& De Haan, 2017).

Although the present study provided an in-depth exploration of teachers' profiles of ICT-related dispositions and its relationship with students' information literacy, several limitations of this study must be recognized. Firstly, because of limited time and accessibility, the sample for this study originates from a specific region of China, which may restrict generalizability of the results. Future research should be conducted with samples of cross-country members. Secondly, it should be recognized that the data collection on teachers' ICT-related dispositions employed self-reporting methods, particular on teachers' educational ICT use and teachers' ICT competence. According to previous related studies, by using self-reported measurements, over-confident teachers may overestimate their competencies while lessconfident teachers may underestimate their competencies (Hatlevik, 2017; Yusuf \& Balogun, 2011). Thus, in the future studies, behavioral research should be conducted especially regarding teachers' educational ICT use for obtaining more accurate information.

In conclusion, the critical contributions of this study are the identification of three teacher profiles across the indicators of their ICT-related dispositions. In addition, this study has confirmed the vital role of teachers for improving students' information literacy. The key implication of this study is that both researchers and practitioners should consider teachers' ICT motivation (external support and intrinsic motivation), teachers' educational ICT use (ICT use for professional development, ICT use for teaching practices, and ICT use for collaboration with colleagues), teachers' attitude toward ICT, teachers' ICT competence, and emphasis for developing students' information literacy to improve students' ICT literacy. 


\section{References}

Aesaert, K., Van Nijlen, D., Vanderlinde, R., Tondeur, J., Devlieger,I., \& van Braak, J. (2015). The contribution of pupil, classroom and school level characteristics to primary school pupils' ICT competences. Computers \& Education, 87,55-69.

Agyei, D. D., \& Voogt, J. (2011). ICT use in the teaching of mathematics: Implications for professional development of preservice teachers in Ghana. Education and information technologies, 16(4), 423-439.

Ainley, J., Banks, D., \& Fleming, M. (2002). The influences of IT: Perspectives from five Australian schools. Journal of Computer Assisted Learning, 18, 395404.

Almerich, G., Orellana, N., Suárez-Rodríguez, J., \& Díaz-García, I. (2016). Teachers' information and communication technology competences: A structural approach. Computers \& Education, 100, 110-125.

Aslan, A. \& Zhu, C. (2016). Influencing factors and integration of ICT into teaching practices of preservice and starting teachers. International Journal of Research in Education and Science (IJRES), 2(2), 359-370.

ACRL. (2016). Framework for Information Literacy for Higher Education. Retrieved October 17, 2021 from, https://www.ala. org/acrl/sites/ala.org.acrl/files/content/ issues/infolit/framework1.pdf.

Baron, R. A., \& Byrne, D. (1987). Social psychology: Understanding human interaction. Washington, DC: American Psychological Association.

Buabeng-Andoh, C. (2012). Factors influencing teachers' adoption and integration of information and communication technology into teaching:
A review of the literature. International Journal of Education and Development using Information and Communication Technology, 8(1), 136-155.

Carstens, R., \& Pelgrum, W. J. (2009). Second Information Technology in Education Study: SITES 2006 Technical Report. International Association for the Evaluation of Educational Achievement. Herengracht 487, Amsterdam, 1017 BT, The Netherlands.

Chigona, A., Chigona, W., \& Davids, Z. (2014). Educators' motivation on integration of ICTs into pedagogy: case of disadvantaged areas. South African Journal of Education, 34(3),1-7.

Choi, M. (2016). A concept analysis of digital citizenship for democratic citizenship education in the internet age. Theory \& Research in Social Education, 44(4), 565-607.

Copriady, J. (2014). Self-motivation as a mediator for teachers' readiness in applying ICT in teaching and learning. Turkish Online Journal of Educational Technology-TOJET, 13(4), 115-123.

Danner, R. B., \& Pessu, C. O. (2013). A survey of ICT competencies among students in teacher preparation programmes at the University of Benin, Benin City, Nigeria. Journal of Information Technology Education: Research, 12(1), 33-49.

De Pablos-Pons, J., Colás-Bravo, P., GonzálezRamírez, T., \& Camacho Martínez-Vara del Rey, C. (2012). Teacher well-being and innovation with information and communication technologies; proposal for a structural model. Quality \& Quantity, 47(5), 2755-2767.

Ferrari, A. (2013). DIGCOMP: A framework for developing and understanding digital competence in Europe. Retrieved September 3, 2021 from http://digcomp. 
org.pl/wp-content/uploads/2016/07/

DIGCOMP-1.0-2013.pdf.

Fraillon, J., Schulz, W., Friedman, T., Ainley, J., \& Gebhardt, E. (2015). International Computer and Information Literacy Study: ICILS 2013: Technical Report. Retrieved September 3, 2021 from https:// www.iea.nl/sites/default/files/2019-04/ ICILS_2013_Technical_Report.pdf.

Fornell, C., \& Larcker, D. F. (1981). Evaluating structural equation models with unobservable variables and measurement error. Journal of Marketing Research, 18(1), 39-50.

Gil-Flores, J., Rodríguez-Santero, J., \& Torres-Gordillo, J. J. (2017). Factors that explain the use of ICT in secondaryeducation classrooms: The role of teacher characteristics and school infrastructure. Computers in Human Behavior, 68, 441449.

Gleason, B., \& Von Gillern, S. (2018). Digital citizenship with social media: Participatory practices of teaching and learning in secondary education. Journal of Educational Technology \& Society, 21(1), 200-212.

Hatlevik, O. E. (2017). Examining the relationship between teachers' selfefficacy, their digital competence, strategies to evaluate information, and use of ICT at school. Scandinavian Journal of Educational Research, 61(5), 555-567.

Helmstadter, G. C. (1964). Principles of psychological measurement. New York: Appleton-Century-Crofts.

Hipp, J. R., \& Bauer, D. J. (2006). Local solutions in the estimation of growth mixture models. Psychological methods, 11(1), 36-53.

Hsu, S. (2010). Developing a scale for teacher integration of information and communication technology in grades 1-9.
Journal of Computer Assisted Learning, 26(3), 175-189.

Jegede, P. O., Dibu-Ojerinde, O. O., \& Ilori, M. O. (2007). Relationships between ICT competence and attitude among some Nigerian tertiary institution lecturers. Educational Research and Reviews, 2(7), 172-175.

Kao, C. P., Wu, Y. T., \& Tsai, C. C. (2011). Elementary school teachers' motivation toward web-based professional development, and the relationship with Internet self-efficacy and belief about web-based learning. Teaching and Teacher Education, 27(2), 406-415.

Katz, I. R. (2007). Testing information literacy in digital environments: ETS's iSkills assessment. Information technology and Libraries, 26(3), 3-12.

Kim, H. S., Ahn, S. H., \& Kim, C. M. (2019). A new ICT literacy test for elementary and middle school students in Republic of Korea. The Asia-Pacific Education Researcher, 28(3), 203-212.

Kim, H. S., Kim, S., Na, W., \& Lee, W. J. (2021). Extending computational thinking into information and communication technology literacy measurement: gender and grade issues. ACM Transactions on Computing Education (TOCE), 21(1), 1-25.

Lai, Y. L., Guo, S. J., \& Tsai, C. H. (2014, October). Using collaborative teaching and inquiry-based learning to help elementary school students develop information literacy and information technology skills. In European Conference on Information Literacy (pp. 436-445). Springer, Cham.

Mathews, J. G., \& Guarino, A. J. (2000). Predicting teacher computer use: $A$ path analysis. International Journal of Instructional Media, 27, 385-392.

Marsh, H.W., O. Lüdtke, U. Trautwein, and 
A.J.S. Morin. (2009). Classical latent profile analysis of academic self-concept dimensions: Synergy of person- and variable-centered approaches to theoretical models of self-concept. Structural Equation Modeling, 16,191-225.

Magidson, J., \& Vermunt, J. (2002). Latent class models for clustering: A comparison with K-means. Canadian journal of marketing research, 20(1), 36-43.

Masoumi, D. (2015). Preschool teachers' use of ICTs: Towards a typology of practice. Contemporary Issues in Early Childhood, 16(1), 5-17.

Meelissen, M. R., \& Drent, M. (2008). Gender differences in computer attitudes: Does the school matter?. Computers in Human behavior, 24(3), 969-985.

Monacis, L., Ceglie, F., Limone, P., Tanucci, G., \& Sinatra, M. (2019). Exploring individual differences among teachers' ICT acceptance: a path model and the role of experience. Human Technology, 15(2), 1795-6889.

Nylund, K. L., Asparouhov, T., \& Muthén, B. O. (2007). Deciding on the number of classes in latent class analysis and growth mixture modeling: A Monte Carlo simulation study. Structural equation modeling: A multidisciplinary Journal, 14(4), 535-569.

O’Dwyer, L. M., Russell, M., \& Bebell, D. J. (2004). Identifying teacher, school and district characteristics associated with elementary teachers' use of technology: A multilevel perspective. Education Policy Analysis Archives, 12, 1-33.

Pastor, D. A., Barron, K. E., Miller, B. J., \& Davis, S. L. (2007). A latent profile analysis of college students' achievement goal orientation. Contemporary educational psychology, 32(1), 8-47.

Papanastasiou, E. C., \& Angeli, C. (2008).
Evaluating the use of ICT in education: Psychometric properties of the Survey of Factors Affecting Teachers Teaching with Technology (SFA-T3). Educational Technology \& Society, 11 (1), 69-86.

Pastor, D.A., K.E. Barron, B.J. Miller, and S.L. Davis. (2007). A latent profile analysis of college students' achievement goal orientation. Contemporary Educational Psychology, 32, 8-47.

Pinder, C.C. (2014). Work Motivation in Organizational Behavior. New York, NY: Psychology Press.

Qizhong, O., \& Qing, Z. (2012, July). Study on cultivation of teachers' ICT ability. In 2012 7th International Conference on Computer Science \& Education (ICCSE) (pp. 1564-1566). IEEE. doi: 10.1109/ ICCSE.2012.6295361

Ramayah, T., Jantan, M., \& Ismail, N. (2003). Impact of intrinsic and extrinsic motivation on Internet usage in Malaysia. Retrieved September 8, 2021 from http://ramayah.com/journalarticlespdf/ impactofintrinsic.pdf

Rosenberg, J. M., Beymer, P. N., Anderson, D. J., Van Lissa, C. J., \& Schmidt, J. A. (2019). tidyLPA: An R package to easily carry out latent profile analysis (LPA) using open-source or commercial software. Journal of Open Source Software, 3(30), 978.

Ribble, M. (2004). Digital citizenship: Addressing appropriate technology behavior. Learning \& Leading with Technology, 32(1), 6-11.

Sang, G., Valcke, M., van Braak, J., Tondeur, J., \& Zhu, C. (2011). Predicting ICT integration into classroom teaching in Chinese primary schools: exploring the complex interplay of teacher-related variables. Journal of Computer Assisted Learning, 27(2), 160-172. 
Senkbeil, M., \& Ihme, J. M. (2017). Motivational factors predicting ICT literacy: First evidence on the structure of an ICT motivation inventory. Computers \& Education, 108, 145-158.

Šorgo, A., Verčkovnik, T., \& Kocijančič, S. (2010). Information and communication technologies (ICT) in biology teaching in Slovenian secondary schools. Eurasia Journal of Mathematics, Science and Technology Education, 6(1), 37-46.

Teo, T. S., Lim, V. K., \& Lai, R. Y. (1999). Intrinsic and extrinsic motivation in Internet usage. Omega, 27(1), 25-37.

The Office of the People's Government of Ningxia autonomous region (2018). Intelligence + Education Demonstration Region Construction Master Plan (2018-2022). Retrieved September 8, 2021 from http://www.nx.gov.cn/zwgk/ qzfwj/201812/t20181226_1232207.html

Tondeur, J., van Braak, J., \& Valcke, M. (2007). Towards a typology of computer use in primary education. Journal of Computer Assisted Learning, 23, 197206.

Tondeur, J., Scherer, R., Siddiq, F., \& Baran, E. (2017). A comprehensive investigation of TPACK within pre-service teachers' ICT profiles: Mind the gap! Australasian Journal of educational technology, 33(3), 46-60.

Tondeur, J., Aesaert, K., Pynoo, B., van Braak, J., Fraeyman, N., \& Erstad, O. (2017). Developing a validated instrument to measure preservice teachers' ICT competencies: Meeting the demands of the 21st century. British Journal of Educational Technology, 48(2), 462-472.

Uluyol, Ç., \& Şahin, S. (2016). Elementary school teachers' ICT use in the classroom and their motivators for using ICT. British Journal of Educational Technology, 47(1),
65-75.

UNESCO. (2010). Towards media and information literacy indicators. Retrieved October 17, 2021 from http://www.unesco. org/fileadmin/MULTIMEDIA/HQ/CI/CI/ pdf/unesco_mil_indicators_background document_2011_final_en.pdf.

Van Laar, E., Van Deursen, A. J., Van Dijk, J. A., \& De Haan, J. (2017). The relation between 21 st-century skills and digital skills: A systematic literature review. Computers in human behavior, 72, 577588.

Wang, M. C., Deng, Q., Bi, X., Ye, H., \& Yang, W. (2017). Performance of the entropy as an index of classification accuracy in latent profile analysis: A Monte Carlo simulation study. Acta Psychologica Sinica, 49(11), 1473-1482.

Yusuf, M. O., \& Balogun, M. R. (2011). Student-teachers' competence and attitude towards Information and communication technology: A case study in a Nigerian University. Contemporary educational technology, 2(1), 18-36.

Yu, L., Wu, D., Zhu, S., Chen, F., \& Zhu, K. (2020). School and Teacher Level Predictors for Students' Information Literacy in Chinese Rural and Urban Education. Proceedings of the 28th International Conference on Computers in Education. Asia-Pacific Society for Computers in Education.

Zhu, S., Yang, H. H., MacLeod, J., Yu, L., $\& \mathrm{Wu}, \mathrm{D}$. (2019). Investigating teenage students' information literacy in China: A social cognitive theory perspective. The Asia-Pacific Education Researcher, 28(3), 251-263.

Zhu, S., Chen, F., Wu, D., Xu, J., Gui, X., \& Yang, H. H. (2020, August). School clusters concerning informatization level and their relationship with students' 
information literacy: A model-based cluster analysis approach. In International Conference on Blended Learning (pp. 77-89). Springer, Cham.

\section{Acknowledgments}

The work was supported by the Key Project of National Education Scientific "13th Five-Year Plan" in 2020, Research on the Connotation, Standard and Evaluation System of Student Information Literacy (project number: ACA200008)

\section{Corresponding author.}

Sha Zhu

Central China Normal University

zhusha@mail.ccnu.edu.cn 